\title{
5. Sociae
}

EISSN 2620-4975

ISSN 1410-3745

\section{PREAH VIHEAR CONFLICT AND THE USE OF MILITARY FORCE}

\author{
${ }^{1}$ Annisa Dewi Cahyaningrum, ${ }^{2}$ Levita Revalina, ${ }^{3}$ Pritta Ayu Khoirunnisaa, ${ }^{4}$ Sri \\ Damayanti Nuur Fadhilah \\ International Relations, President University, Cikarang, Indonesia \\ ${ }^{1}$ annisa.cahyaningrum@student.president.ac.id, ${ }^{2}$ levita.revalina@student.president.ac.id, \\ ${ }^{3}$ pritta.khoirunnisaa@student.president.ac.id, ${ }^{4}$ sri.fadhilah@student.president.ac.id
}

\begin{abstract}
Preah Vihear is one of the temples located in Cambodia. That place is known as a Hindu religious site that is very important for worship activity. As important as this site is, Cambodia and Thailand have conflicted not only once but twice regarding ownership of the Preah Vihear complex. A row over territory around Preah Vihear's 11th Century temple continues to strain relations between Thailand and Cambodia. The first conflict happened in the 1950s, while the second one started in 2008. Focusing on the second conflict, this paper studies about reasons for the re-emerge of the conflict after decades, the use of military forces in resolving this conflict, the factors that might encourage the use of military force, and the role of ASEAN in attempt to solve the problem as a regional organization that has both Cambodia and Thailand as the members using realism theories.
\end{abstract}

Keywords: Preah Vihear conflict, Thailand, Cambodia, Military force, Realism

DOI: $10.33541 /$ sp.v20i1.2415

Sociae Polites : Majalah Ilmiah Sosial Politik

Faculty of Social and Political Science, Universitas Kristen Indonesia

ISSN 1410-3745 print/ ISSN 2620-4975 online

Volume 20, Number 1 (January - June 2019)

Pages 81-92 


\section{Introduction}

International Relations theory has several different perspectives in its study, including Realism. Realism is one of the most dominant and influential views on international relations. The history of realism theory is, since the end of World War 2, Realism has dominated the scholarly study of international relations. Realists claim to provide both the most detailed interpretation of state actions and a set of policy prescriptions. This theory emphasizes that the state is the main actor in International Relations. Other actors such as organizations and individuals exist too, but the power is not as strong as the state's power. National interest also becomes the focus of this theory. Scholars of realism theory believe that selfishness and our desire to have the capacity and incapability to trust another person will lead to a predictable outcome (ANTUNES and CAMISãO 2018). The state is an actor in the international system that prioritizes its national interests to defend and guarantee its security, sovereignty, and survival. It means a State that has more power would likely win in a dispute. International politics is full of conflicts and tension because there is no supreme authority. There are no states able to regulate the behavior of other states within the international system.

Concerning the spatial concept, the boundary of state sovereignty is significant in the dynamics of the relationship between nation-states because boundaries between states often caused an open conflict between states. Oxford dictionary has defined a border as "A line separating two countries, administrative divisions, or other areas" (OxfordDictionaries 2020). The 'line' itself can be in the land territory, water territory, or air territory. The border is not an ordinary line because it is crucial to separate two or more states legally. This line is later called boundary when it comes to limiting political entities such as governments or states. Preah Vihear Temple is a temple that reflects Hinduism, which was built in the $11^{\text {th }}$ century and part of the Angkor Wat temple sites located in Cambodia. The Preah Vihear temple becomes the place of the conflict of the border between Thailand and Cambodia. The border conflict between Thailand and Cambodia regarding Preah Vihear temple territory has occurred for an extended time.

This study focuses on why both Cambodia and Thailand choose to use military power in resolving this problem rather than using the diplomatic way in the context of the Preah Vihear conflict that happened from 2008 until 2012. The International Court of Justice (ICJ) becomes the third party in this conflict. The conflict at first was possible to be resolved by the ICJ as the 3rd party. In 1962, after the ICJ ruling regarding border conflicts, the two countries agreed to stop mentioning disputes regarding the Preah Vihear temple's boundaries. But as time went on decades after the final decision from ICJ, precisely in 2008, Thailand refused the decision of ICJ back in 1962 again. The explanation for Thailand's refusal was because Thailand considered that this Temple failed to belong to Cambodia alone. Cambodian people could not only perform worship within the Preah Vihear temple, Thailand, but those who live around this Temple may also worship at the Temple.

Additionally, the Temple's entrance area opens to the north with easy accessibility for Thailand, and Thailand considers that it was built to be a site of worship for Thailand. Thailand asked the United Nations Educational, Scientific, and Cultural Organization (UNESCO) to review its decision regarding the supply of Preah Vihear temples. However, UNESCO refused Thailand's request because it was considered valid to designate the Preah Vihear temple as a part of Cambodia's sovereignty. On July 7, 2008, UNESCO 
officially announced that the Preah Vihear temple was crowned a world heritage in 2008 (UNESCO 2008). The Cambodians are undoubtedly pleased with this.

In contrast to the Thailand side, Thailand's domestic situation became unstable; just per week after the Preah Vihear temple was crowned a legacy in 2008, the Cambodian side saw no Thailand protesters crossing the disputed area. Then, on July 15, 2008, the Cambodian side also claimed 40 Thailand soldiers entering the Frangipani territory are within the Preah Vihear Temple's vicinity. Then, the Cambodian side began to repress Thailand's access to the Preah Vihear temple. This action is often done by Cambodia, of course, to guard the sovereignty of the country.

The Cambodian government tried to warn Thailand about the incident. Still, Thailand considered that it was done to shield its country's sovereignty or land near the frangipani border (BBC 2013). Due to this, the Cambodian government placed its military within the area of the Preah Vihear temple. Cambodia has done the identical thing to defend its sovereignty. It is estimated that Thailand, in its military deployment at the Preah Vihear temple area, has 2,000 troops while Cambodia has quite 3,000 soldiers (Frederickson 2012). The result was the primary army battle between the two sides around the Preah Vihear shrine in October 2008. This development resulted in an increasingly dangerous situation, which becomes a gun battle between the two countries' militaries. Gun battles continued within the following year in April 2009, which left 2 of the Thailand and Cambodian soldiers dead and several other injured. It is considered a questionable action from both states because they once resolve the Preah Vihear territory's conflict with ICJ as the $3^{\text {rd }}$ party. An efficient resolution can be achieved. Why did both states choose to use the military rather than solve it diplomatically while reflecting on past events and resolutions? Especially in 2008, the Association of Southeast Asian Nations (ASEAN) was already established and could be a closer $3^{\text {rd }}$ party than ICJ.

Not only that, military clashes between the two countries continued again in January 2010, April 2010, and June 2010, which at that point had killed eight soldiers from the Thailand side. Then between 4 and seven February 2011, another gun battle occurred, which killed 2 Thailand soldiers, one civilian, and three Cambodian soldiers (Wagener 2011). The border conflict between the two countries is getting further; in April 2011, it had been reported that the military from either side clashed again within the border area and killed 4 Thailand soldiers and three Cambodian soldiers. As a result of these clashes, the lives of soldiers from each side of the dispute have killed civilians, displaced people, and destroyed the property of the people living along with the border areas of the Preah Vihear temple. The clash resulted in material damage to the Preah Vihear temple. During this conflict, the two countries are indirectly disadvantaged by sacrificing their soldiers, providing refugees with food, and providing safe shelter. In 2011, when the two countries were still fighting between their militaries, they got a reaction from the global organization and condemned and asked Thailand and Cambodia to resolve the conflict as soon as possible. Even UNESCO also sent envoys to fulfill with the Prime Ministers of Thailand and Cambodia to debate safeguarding the Preah Vihear temple's planet heritage and requested that both parties protect the Preah Vihear temple.

This study aims to contribute to the studies of conflict between states by examining military force in the dispute of territorial claims and border conflict between Thailand and Cambodia regarding the Preah Vihear temple site by using the theory of Realism. The dispute that began way back decades ago re-emerge in 2008, and the use of military power needed to discuss why it is used when other resolutions might be made. Considering other factors, both internal and external, that might encourage military force 
in the sacred and holy place used for worship. Both advantages and disadvantages of military action would measure whether the military forces are needed to resolve the conflict.

\section{Literature Review}

This section of the paper reviews the works of literature that study realism theory, the factors that caused the conflict of Preah Vihear, and how the domestic political and political actors' interests affected this conflict. Realism theory is one of the most used approaches in International Relations study. Realism is a theory that explains how the reality of international politics is because it points out that obstacles that exist in international politics are results from human nature and the absence of supreme authority over the state. Realists also judged states' behavior according to the ethics of responsibility because the goal is the survival of the State (ANTUNES and CAMISãO 2018). This theory emphasizes the role of the state as the main actors in the international system. The state is the main actor with the most significant power. The state will put first the survival of the state and set aside other affairs. To survive the international system's cruelty, each state will have a different way, depending on its power and national interests. State with substantial military power would likely use the military force when there is a threat or when the only way to achieve the national interests is using military power. The reasoning of this conflict that first emerges at the beginning of the Cold War era is mostly affected by historical motives. The Preah Vihear temple that belongs to Cambodia according to the Annex 1 map and treaty between French Indochina and Siam back in 1907 were occupied by the Thailand troops in 1954, claiming that the temple site belongs to Thailand, which caused a clash in the temple site (Strate 2013). These historical motives, of course, affect the conflict so much. Preah Vihear temple, which is part of the famous Angkor Wat temple site, is a critical heritage and means a lot for the country that owns it as it is not just a pile of stones. Still, it is both a religious site and sacred and could be a tourist investment that would benefit the country.

As the Cambodian government decided to bring this case to the International Court of Justice back in 1959 and resolved by the Court, the conflict did not stop there as it repeats after decades, even worse with more hard power involved. The root of why this conflict re-emerged in 2008 is when Thailand lose the territory back in the 1930s (Strate 2013). But on the other hand, the loss of territory might not be the only cause of this conflict. The political actor's personal motives from both states, Hun Sen as Cambodia Prime Minister and Abhisit Vejjajiva as Thailand Prime Minister at that time, also stand out and are considered one of the main motives caused this border conflict to rise (Wagener 2011). Both Hun Sen and Abhisit Vejjajiva defend the territory mainly by connecting it to the historical context. But if it is really about the territorial dispute, which means that the state sovereignty is at stake, the use of low intensity of conflict is questionable and worth discussing. The low intensity of conflict can be seen from both Thailand and Cambodia sides. Neither of them prepares massive military armed troops or enormous military escalation during the conflict period.

However, it is believed that the main aim of low-intensity conflict in this conflict is because both Hun Sen and Abhisit Vejjajiva were trying to distract the society and citizens from domestic problems and make people focused more on the international border dispute conflict. Thailand was having a domestic political crisis from 2006 until 2008. It first emerged when the opposition parties of the former prime minister, Thaksin 
Shinawatra, start to do a movement to topple down him in Bangkok (McCargo 2009). Considering that the use of low-intensity conflict did not use a lot of budget spending on armed troops and weapons, also to minimalized the possible deaths and fatalities from both army and civil citizen, and to preserve the sacred temple site which might cost a lot of money if it is destructed because of a large scale of war, but it is still able to take the citizen's attention for a quite time makes this argument becomes logic. There is also a study that suggests Abhisit Vejjajiva; at that time, seize the Preah Vihear to become Thailand Prime Minister and use coercive means in this conflict. It is suggested that Abhisit Vejjajiva use the Preah Vihear conflict to encourage the emergence of Thailand citizens' nationalism sentiment. In an attempt to solve this conflict, Abhisit also tries to gain support from the government pressure group named the People's Alliance for Democracy (PAD).

On the other side, Hun Sen also uses this conflict to secure his position as prime minister in the next election that will be conducted not far from the timeline of this conflict's emerge (Putri and Muhyidin 2019). As mentioned earlier, the Preah Vihear temple site is critical since it is part of the Angkor Wat temple, the largest religious site in the world placed on the land. That is why Preah Vihear is crucial for Cambodia and all Cambodian citizens, which becomes a national pride. No matter what, Preah Vihear must remain as part of Cambodia's heritage. Hun Sen saw this as a big chance to maintain his position by resolving the conflict, claiming the Preah Vihear as Cambodia's heritage, and winning the Cambodian people's hearts (Putri and Muhyidin 2019). As there is a lot of research that studies about how did the conflict happened and what is the factors behind the conflict, this study will focus on contributing to the studies as to why the military movement, even in a low intensity and hard power, is chosen to be the resolution rather than the soft, diplomatic way in this conflict of Preah Vihear, despite all the factors that affect the cause of the conflict.

\section{Research Method}

Two types of research methods can be used, which are the Qualitative Method and the Quantitative Method. However, the research method that is used for this paper is the qualitative method by doing library research on original documents, journals, and books. The purpose of the use of the qualitative method is:

1. To understand the general background of the Preah Vihear conflict

2. To understand factors that affect the Preah Vihear conflict

3. To understand the connection between realism theory and emphasize the state's interests and power to the Preah Vihear conflict

4. To understand factors that encourage the use of military force by both parties

5. To understand the role of ASEAN as a regional organization in solving the conflict.

For this study, choosing a qualitative method would make it easier to understand the core problems as qualitative data expressed by words would capture what is needed to answer the research question determined earlier. Searching for the data that already exists and using it as a guide for solving the questions indeed are the best option. But as the conflict of Preah Vihear happened years ago and the pandemic situation nowadays, it 
becomes harder for us to search for primary sources like doing interviews or observation as the conflict occurred in the past. For this paper, we tend to use the secondary sources collected by someone else, like journals, books, official reports, and valid news related to this conflict.

The case study materials that we chose have criteria such as valid news or journals that studied or contained reasons why the conflict happened and what factors affect the re-emerge of the Preah Vihear conflict. We also use the study of realism theory of International Relations to connect the conflict of Preah Vihear and the reason that encourage the use of military force in resolving this conflict, as we also use valid data that available online about both states' military power to compare and determine did military power affect the use of military force in resolving this conflict. We tend to process the data by analyzing deeply by focused reading on the content that passed the criteria and can be a valid source to find the precise data.

\section{Results and Discussions}

In relations between states, there are always cooperation, competition, and conflict. During the process and the relations mentioned earlier, a state must maintain the national interests using the power that that state has. Since a long time ago, territorial disputes or border conflicts between states have been among the main reasons for escalating war or military power between states. From the realists' perspective, the war in international politics is unavoidable because there is a never-ending struggle between states regarding power (Kocs 1995). Realism is one of the theories of international relations that emphasizes the role of the state, the state's national interest, and the use of military power in world politics. The assumption of Realism is that the state is the main actor and has the most crucial role in international relations. Realists do not think that there will be non-state actors; it's just that non-state actors are not recognized for their roles. Second, the state is viewed as a unitary actor. The state can at least make a policy on a specific issue. Third, the state is essentially a rational actor. And the fourth is, National Security usually tops the list. Realists consider that security to be the most important part of interactions between countries. Realism is competitive and conflictual, which holds the view that a country must compete with other countries in gaining power and resolving problems with conflict or war. Realists believe that relations between countries are in a system of international anarchy, a system where there is no power over the state. Realist thinkers also place national security as a priority or focus from the perspective of Realism.

In the realist view, military security and strategic issues are classified as the main interests and refer to the category of high politics. In contrast, realists see the economy and social issues as commonplace, which falls into the category of low politics. Realism focuses on the potential for conflicts between countries. The importance of security is at the top of the list of every actor's interests, which is a sovereign state. In conclusion, the realist paradigm is primarily regarded as one that is obsessed with power. It is governed by the concepts of statism, self-help, and survival, knowing that the state must pursue power, and is considered the main actor in international politics. It is known that territory is one of the main elements of a state; that is why every state would defend their own claims with the use of power in every territory dispute. Power itself can be categorized as two, which are soft power and hard power. For soft power, the most straightforward example is diplomacy. The use of soft power means that there are no harm, casualty, and 
damage, which is contrary to the use of hard power. The use of hard power, especially military force, includes violence and generally caused damage and would need more budget spending (Li 2018). Even with all the disadvantages that might happen caused by using military force, it is still used in a lot of attempts to resolve a conflict.

Cambodia bases its argument on a map; Annex 1 Map, made by French officials in 1907, some of which were members of the Mixed Commission formed under the Boundary Treaty between France and Siam on February 13, 1904 (Sang Kook 2014). This commission was established by France and Thailand and was responsible for surveying a boundary line according to the treaty's terms. On the other hand, Thailand argues that the map is not binding because an authorized member did not make it to the Mixed Commission. Furthermore, the boundary line used in the map is based on the wrong watershed line. When using the correct watershed line, the Preah Vihear Temple will be located within Thailand's territory. So, in 1962, The International Court of Justice ruled that the two countries' military be withdrawn in a comprehensive manner and simultaneously from an area of 17.3 kilometers around the Preah Vihear Temple, which was designated as a demilitarized area. Instead, the police of the two countries will be deployed at the two borders.

In 2008, the escalation of the conflict between Thailand and Cambodia occurred again after the decision of Preah Vihear as a world heritage belonging to Cambodia in 2008 (Silverman 2010). The current conflict is exacerbated by the instability of Thailand's domestic politics. The Thailand nationalist movement used the Preah Vihear issue to overthrow Prime Minister Samak Sundarajev (Farida 2014). Initially, the Thailand government under Prime Minister Samak Sundarajev stated that Thailand would support the Preah Vihear temple in the world heritage list, stating that the agreement was not included in the disputed territory; in other words, it should not affect the disputed boundaries. Then, this caused the anger of the Thailand nationalist movement. The PAD movement was demonstrated near the Preah Vihear temple and caused chaos in the border area. The Cambodian government responded to this; therefore, the Cambodian government closed the border around Preah Vihear to people from Thailand. Apart from that, the opposition party also used this to overthrow the Samak government in Thailand. The opposition Democratic Party is in coalition with the PAD movement in its rejection of the registration of the Preah Vihear temple with the UNESCO.

The disputed area is the area around Preah Vihear temple, which is 4.6 square kilometers of land. Thailand claims were made against the land to be claimed based on an interpretation of the ICJ ruling in 1962, which was limited to sovereignty over the Preah Vihear temple area. Still, the boundary did not have the legal status of the decision that had been issued. The conflict that has ended has now entered a new era; what is being contested is the land in the vicinity that is close to the Thailand border area. Thailand's land was demanded for ownership, while the ICJ ruling made it clear that the Preah Vihear temple belonged to Cambodia. To overcome the Preah Vihear conflict, Cambodia and Thailand also carried out a dispute resolution process. Negotiations carried out in the 2008 meeting between Prime Minister Samak Sundarajev and Prime Minister Hun Sen resulted in the decision to withdraw the military from the disputed territory. Still, it is not clear when the withdrawal will take place (Adolf 2008). Apart from negotiating efforts to find a solution to the border conflict between Thailand and Cambodia, efforts to involve third parties are also carried out by involving the United Nations (UN), ICJ, and ASEAN. According to Thailand, unlike Cambodia, the settlement process can be appropriately resolved if only by the negotiation method. Meanwhile, Cambodia wants a third party to 
work together to resolve the conflict. Before ASEAN handled this case, Cambodia reported this case to the UN, but the United Nations referred to it again to ASEAN.

However, Thailand's military power is way more excellent compared to Cambodia's military power. Thailand has a more trained army, and the Thailand government's defense budget is very high, which means Thailand can afford more military force in resolving this conflict. The more vital military force that Thailand has might encourage the use of military power from Thailand, knowing that the opposition, Cambodia, might be overwhelmed to overcome the armed troops. In April 2009, soldiers of the two countries shot each other across the disputed border. In February 2011, at least eight people died within days of fighting. In April, widespread clashes forced tens of thousands of people to leave the area around the dispute (BBC 2013). The residents who live around the temple area are forced to leave their homes even though the residents living in the area are part of the two conflicting countries' people. But despite the strong military force, there are suggestions that the use of low intensity of power in this conflict is just a diversion for both parties, Thailand and Cambodia. As in 2008, Thailand experienced a political crisis, which could be considered a domestic issue (Chomthongdi 2009).

That is why the low intensity of military force is being used because this is part of a diversion of the issue to distract the Thailand people from the internal state problems. If Thailand chooses to use high intensity, the costs will definitely be a lot, which can be detrimental to the country, considering that Thailand may not be completely concerned about this because it wants to claim Preah Vihear and needs this conflict to cover other cases. This does not mean that Thailand does not care about the Preah Vihear territorial claims. Still, there is a possibility that this is not entirely the reason why Thailand chose to use military forces. From the Cambodian side, the use of military forces is needed to protect Preah Vihear sites. However, the use of military forces, which was initially intended to maintain Preah Vihear, changed after Thailand used violence in an attempt to claim the Preah Vihear temple. Cambodia could not stay still since Preah Vihear is part of the nation's pride, and the use of military power to hold back the Thailand troops and protect the Preah Vihear site is partially reasonable.

On the other hand, Cambodia certainly has several options that can be chosen to minimize bloodshed or the use of military force in holy and sacred places, especially Cambodia as the legal owner of the territory based on the ICJ decision in 1962 then certainly better understand the conditions around Preah Vihear and understand that the use of military force in places of worship may not be the right thing. But it cannot be denied that Thailand was not responsible and did not obey the judges' binding decision back in 1962, which could be considered a rebellious act towards the decision of ICJ as $3^{\text {rd }}$ party, and those acts were irresponsible. It is such a shame that Thailand, as a 'bigger' state than Cambodia, was doing those acts with the perception that Cambodia is 'smaller' and cannot do anything about that. Even though Thailand has great military power and way more vital than Cambodia, the fact that Thailand lost in the Court in 1962 proved that in the eyes of the Court, all the power that Thailand has did not matter and defeated by Cambodia that has valid proof, which is Annex 1 Map. It shows that the ICJ judges are not influenced by military power. This fact contrasts with the Realism theory that argues states with more power will be dominant or win disputes within the international system. Realism theories fail to describe that a state would win in a dispute with a particular situation only, where the military power is valid and used as a benchmark. Maybe if Cambodia and Thailand choose to do war or military aggression to fight over 
the Preah Vihear temple without bringing this case to the ICJ, there is a possibility that Thailand could win the dispute.

Meanwhile, on the other hand, the reason behind the formation of ASEAN is the frequent conflicts between Southeast Asian regions (Nesadurai 2008). The formation of ASEAN as a regional mechanism to help improve relations between countries and build a unity of countries divided due to differences in ethnicity, language, culture, and religion apart from ASEAN is also shaped by bringing the political and security interests of its member countries. ASEAN began as a mediator in 1988-1989. In its implementation, ASEAN has its own norms, which are known as the ASEAN Way. The ASEAN Way deals with norms of non-intervention, non-use of armed forces, pursuing regional autonomy, and avoiding collective defense (Khoo 2004). At that time, Indonesia hosted the Jakarta Informal Meeting (JIM) when resolving the conflict between Cambodia and Vietnam. ASEAN is a positive contributor to the solution to various global problems in the world because ASEAN was formed to become a regional organization in Southeast Asia. The world's global problems are formed because of conflicts in a country. In this case, ASEAN also acts as a third party helping between the two disputing countries. The role of ASEAN can be seen from Indonesia, which at that time was the chair of ASEAN who acted by appealing for the conflict to be resolved peacefully without a ceasefire. But as a mediator, ASEAN faces various obstacles in resolving disputes in the two countries. The Minister of Foreign Affairs from Indonesia has invited Foreign Ministers from Cambodia and Thailand. The two foreign ministers' meeting with the Indonesian foreign minister who was the chair of ASEAN carried out a 'Shuttle Diplomacy,' namely the back and forth diplomacy carried out by Indonesia with the two countries in dispute.

It is evident in the principles that have been implemented by ASEAN so far, which have been reflected in the Treaty of Amity and Cooperation in Southeast Asia (TAC) and the ASEAN Charter. (NTI 2019). The two countries have pledged to resolve their differences and disagreements by peaceful means and to reject aggression and the use and threat of force of arms. ASEAN tends to limit foreign intervention that is too deep. The settlement effort through diplomacy is better and is considered more elegant, but in the process, a bargaining tool is still needed, such as military force. The dispute settlement of Thailand and Cambodia is not a member settlement mechanism in the ASEAN declaration. What is in the ASEAN declaration is increasing efforts to develop institutions such as creating norms and formal mechanisms to be able to resolve disputes between Thailand and Cambodia peacefully.

\section{Conclusions and Recommendations}

Preah Vihear temple is a very important heritage. It means a lot for a country that owns it as it does not just pile of stones, but it is both a religious site and sacred and could be a tourist investment that would benefit the country that owns it. And at the same time, Preah Vihear, a holy place for worship located within the border between Cambodia and Thailand, has been seizure done by Cambodia and Thailand. Decades ago, precisely in 1962, in its Judgment at the merits, the International Court of Justice determined that the Temple of Preah Vihear was located in territory below the sovereignty of Cambodia and in consequence, that Thailand was beneath an obligation to withdraw any military or police forces, or other guards or keepers, stationed at the Temple, or in its vicinity on Cambodian territory. This decision made by the Judges is not influenced by any military power, proving that Thailand loses the case even though Thailand has more excellent 
military power. But in 2008, the conflict re-emerged after, on July 7, 2008, UNESCO officially announced that the Preah Vihear temple was crowned a world heritage in 2008. Then, on July 15, 2008, the Cambodian side also claimed 40 Thailand soldiers entering the Frangipani territory are within the Preah Vihear Temple's vicinity. Then, the Cambodian side began to repress Thailand's access to the Preah Vihear temple. This action is often done by Cambodia, of course, to guard the sovereignty of the country. The gun battles occurred for years after, in 2012, all the troops leave the area. The conflict becomes attention because of the use of military force to resolve it.

Generally, territory conflict or border disputes lead to war because it is one of the country's main elements. Still, in this case, the re-emergence of this conflict and the use of military force is affected by the state's power and internal state problem. For the reasons of the use of military force from Thailand side, as in 2008, Thailand experienced a domestic political crisis, the re-emerge of Preah Vihear conflict might become one of the distractions that Thailand government do to make Thailand people's focus divided, which this action is supported by the fact that Thailand's military power is more prominent than Cambodia's. Meanwhile, the use of military force from Cambodia that at first is aimed to protect the Temple changed becomes to fight back the Thailand army. Preah Vihear is part of the nation's pride. Military power to hold back the Thailand troops and protect the Preah Vihear site is partially reasonable since the diplomatic way did not work correctly. It cannot be denied that the use of military force from Thailand in the first place was not right since it means that Thailand did not obey the ICJ judge's decision in 1962. And as previously explained, Realists see that security and strategic military issues are classified as main interests and refer to the high political category. The realist paradigm is regarded as one that is obsessed with power. The weakness of realism theories is that they failed to emphasize how the state would have won a dispute or dominant in the international system with a particular condition. And it is known that territory is one of the main elements in a country; therefore, Thailand will defend its claim by using power. Power itself is categorized into two, namely soft power and hard power. In this conflict, the use of hard power or military force in resolving it relates to the realism theory, where a state's national interests play a significant role. It was evident that Thailand is pursuing power by using military force, which is considered a formidable power to achieve national interests, which is claiming the Temple. Meanwhile, on the other hand, Cambodia's use of military force is because they defend their territory. The use of military force becomes an 'obligation' because there is no other way to protect the Temple besides using the military force. Since Preah Vihear is a precious site and a place to worship, it is expected that this kind of military force in resolving conflict will never emerge again, whatever the reason is. 


\section{BIBLIOGRAPHY}

\section{Books}

Adolf, Huala. 2008. Hukum Penyelesaiaan Sengketa Internasional. Jakarta: Sinar Grafika.

\section{Journals}

Chomthongdi, Jacques-chai. 2009. "Thailand and the World Financial Crisis." April 20. Accessed October 29, 2020. https://www.theglobalist.com/thailand-and-theworld-financial-crisis/.

Farida, Elfia. 2014. "Penyelesaian sengketa Perbatasan antara Thailand Dengan Kamboja Melalui Mekanisme ASEAN." Masalah - Masalah Hukum 43 (1): 5766. Accessed October 28, 2020. doi:10.14710/mmh.43.1.2014.57-66.

Khoo, Nicholas. 2004. "Deconstructing the ASEAN security community: a review essay." International Relations of the Asia-Pacific 4 (1): 35-46. Accessed October 29, 2020. doi:10.1093/irap/4.1.35.

Kocs, Stephen A. 1995. "Territorial Disputes and Interstate War, 1945-1987." The Journal of Politics 57: 159-175. Accessed October 28, 2020. doi:https://doi.org/10.2307/2960275.

Li, Eric. 2018. "The Rise and Fall of Soft Power. Foreign Policy." August 20. Accessed October 25, 2020. https://foreignpolicy.com/2018/08/20/the-rise-and-fall-ofsoft-power/.

McCargo, Duncan. 2009. "Understanding Thailand's political crisis." E-International Relations. April 24. Accessed December 5, 2020. https://www.eir.info/2009/04/24/understanding-thailand\%E2\%80\%99s-political-crisis/.

Nesadurai, Helen E. S. 2008. "The Association of Southeast Asian Nations (ASEAN)." New Political Economy 13: 225-239. Accessed October 29, 2020. doi:10.1080/13563460802018588.

Putri, Indah Merdeka, and Ali Muhyidin. 2019. "Cambodian and Thai Political Actors Interest in Preah Vihear Temple Border Conflict in 2008-2011." Jurnal Politik: The Public Sphere and Political Participation 4: 216-236. Accessed November 20, 2020. doi:https://doi.org/10.7454/jp.v3i2.73.

Sang Kook, Lee. 2014. "Siam Mismapped: Revisiting the Territorial Dispute over the Preah Vihear Temple." South East Asia Research 22 (1): 39-55. Accessed October 28, 2020. doi:https://doi.org/10.5367/sear.2014.0196. 
Silverman, Helaine. 2010. "The ongoing temple dispute between Thailand and Cambodia and UNESCO's World Heritage List." International Journal of Heritage Studies 17 (1): 1. Accessed October 28, 2020. doi:https://doi.org/10.1080/13527258.2011.524001.

Strate, Shane. 2013. "A Pile of Stones? Preah Vihear as a Thai Symbol of National Humiliation." South East Asia Research 21 (1): 41-68. Accessed November 20, 2020. doi:https://doi.org/10.5367/sear.2013.0139.

Wagener, Martin. 2011. "Lessons from Preah Vihear: Thailand, Cambodia, and the Nature of Low-Intensity Border Conflicts." Journal of Current Southeast Asian Affairs 30 (3): 27-59. Accessed November 19, 2020. doi:https://doi.org/10.1177/186810341103000302.

\section{Internet Sources}

ANTUNES, SANDRINA, and ISABEL CAMISãO. 2018. "Introducing Realism in International Relations Theory." E-International Relations. February 27. Accessed November 18, 2020. https://www.e-ir.info/2018/02/27/introducingrealism-in-international-relations-theory/.

BBC. 2013. "Preah Vihear temple: Disputed land Cambodian, court rules." November 11. Accessed October 29, 2020. https://www.bbc.co.uk/news/world-asia24897805.

Frederickson, Terry. 2012. "Troops leave Preah Vihear area." July 19. Accessed October 29, 2020.

https://www.bangkokpost.com/learning/advanced/303217/troops-leave-preahvihear-area.

NTI. 2019. ASSOCIATION OF SOUTHEAST ASIAN NATIONS (ASEAN). March 26. Accessed November 28, 2020. https://www.nti.org/learn/treaties-andregimes/association-southeast-asian-nations-asean/.

OxfordDictionaries. 2020. border. Accessed February 28, 2020. https://www.oxfordlearnersdictionaries.com/definition/english/border_1.

UNESCO. 2008. "Temple of Preah Vihear." Accessed October 26, 2020. https://whc.unesco.org/en/list/1224/. 